\title{
The Efficiency and Profitability Level of Indonesia Banking System Adopting Fintech in 2018
}

\author{
Hartini,* Jakaria \\ Faculty of Economics and Business \\ Universitas Trisakti \\ Jakarta, Indonesia \\ *hartini.fe@trisakti.ac.id
}

\begin{abstract}
This study aims to examine the efficiency and profitability level of the Indonesian banking system with and without the use of fintech technology. This is a quantitative research, with data obtained from the 96 banks in 6 groups published in the 2018 financial statements in accordance with the adaptation of fintech. A total of six input variables namely Total Deposits, Total Equity, Fixed Assets, Interest Expenses, Salaries Expenses and Total Operating Expense and four output namely Total Loans, Investment Securities, Interest Income and Operating Income, were used in this research. The result showed that the average achievement of the efficiency and profitability of banks that adopt the use of fintech was significantly different from those that do not adopt its usage. The optimal efficiency level of non-foreign exchange commercial banks, State-owned banks, and other banks that adopt this this technology has an average efficiency index of $100 \%, 90-99 \%$ and $80-90 \%$.
\end{abstract}

Keywords-efficiency, fintech, banking, data envelopment analysis

\section{INTRODUCTION}

Currently, developing countries, especially in Asia and Africa have adopted the use of financial technology in its daily banking activities. The frequent changes in consumer behaviour led to the design and development of this digitalbased system. Fintech 3.0 emerged as a reaction to the financial crisis in the West, however, in Asia and Africa, the economy mainly drove its recent development [1].

For decades, banks invested in technology to improve the efficiency of its financial innovation systems. This led to the development of various FinTech-based innovations such as Electronic Point-of-Sale (EFTPOS) fund transfers, automated teller machines (ATMs), internet banking, international electronic fund transfers with the Society for Worldwide Interbank Financial Telecommunications (SWIFT), Electronic Data Interchange (EDI), mobile banking, Bitcoin wallet, Block chain banking, and crowdfunding [2].

According to empirical studies, companies that provide services related to fintech are still relatively few compared to the number of consumers. Abdul-Wahab and Haron examined the efficiency of the banking industry in Qatar by using Data
Envelopment Analysis (DEA) and found that they operated below their optimal performance even though the ability increased over time [3]. In terms of technical proficiency, conventional banking is better, while Islamic banking is more efficient in scale. Furthermore, when compared to Islamic banking, the average technical efficiency of conventional and foreign banks declined from 2008-2009 due to the global financial crisis.

Therefore, this research was conducted to determine the efficiency levels of conventional banks that adopt the use of fintech with those that do not utilize this technology.

\section{LITERATURE REVIEW}

Arner et al defined Fintech as the use of technology to provide financial solutions [4]. It is also described as technological innovation in financial services that produce business models, applications, processes or products with material effects [5].

The recent evolution of Fintech started with credit card innovations in the 1960s, as well as debit cards and terminals that provided cash, such as automatic teller machines (ATMs) in the 1970s [4,5]. The emergence of telephone banking subsequently followed this in the 1980s and various financial products following the deregulation of capital markets and bonds in the 1990s. Furthermore, internet banking emerged and encouraged the existence of branchless and remote banking activities. With this change, customers no longer need to physically meet with the bank, as they can easily carry out their daily financial transactions using mobile technology (mobile). This change has led to the emergence of direct financing and intermediation, which is predicted to replace indirect, expensive and inefficient methods [6].

The technological innovation is not a new phenomenon in the financial sector due to its long history of symbiosis, therefore, inherently financial technology, also known as Fintech, is not a new development for the industry. However, the intensity of discussion and study on it is quite high, due to its fast penetrating ability. This issue is also a concern of many parties at various levels in Indonesia, both among decision- 
makers, academics, financial business practitioners and the public (community) as consumers or users of Fintech [7].

According to Coopers, technological advancements increase the number of digital device users, lifestyle changes that lead to an increase in the market potential for digital banking and also the migration of conventional banking users to digital banking [8].

\section{METHODS}

The quantitative data envelopment analysis (DEA) was used to determine the input and output variables used in advance. Meanwhile, ANOVA was used to test the differences in profitability efficiency between banks that adopt and do not adopt fintech.

The purposive sampling method was used to obtain data from conventional banking in 2018 with complete financial statements to the FSA. Data were obtained from a total of 96 banks consisting of 4 State-owned banks which adopted fintech, 36 Foreign Exchange Private Commercial Banks where 25 adopted fintech and 11 failed to adopt its usage, 16 Non-Foreign Exchange Private Commercial Banks where 2 adopted fintech and 14 failed to adopt its usage, 23 Regional Development Banks (BPD) where 4 adopted fintech and 19 failed to adopt its usage, 9 Mixed banks where 8 adopted fintech and 1 failed to adopt its usage, and 8 Foreign banks where 6 banks adopted fintech and 2 failed to adopt its usage.

The variables used in this research were grouped into two, as follows. First, Output variable this consists of the following 4 variables: Total loans channelled from each bank, Investment Securities, Interest income, and Operation income received by each bank. Second, input variable this consists of the following 6 variables: Total third party funds raised by each bank, Total equity capital, fixed assets owned by each bank, Interest expense issued, Salaries expense of employees, and Total operations expense.

A total of two analytical tools were used in this research as follows:

\section{A. Data Envelopment Analysis (DEA)}

This is the analytical tool used to solve this research problem which is stated by the following equations

Purpose function: Maximum $Z_{k}=\sum_{r=1}^{s} U_{r k} \cdot Y_{r k}$

With limitations or constraints:

- $\quad \sum_{r=1}^{s} U_{r k} \cdot Y_{r k}-\sum_{r=1}^{s} V_{r k} \cdot X_{r k} \leq 0 ; \mathrm{j}=1, \ldots, \mathrm{n}$

- $\sum_{r=1}^{s} V_{r k} \cdot X_{r k}=1$

Where:

$\mathrm{U}=$ Weight for output

$\mathrm{Y}=$ Output variable

$\mathrm{V}=$ Weight for input

$\mathrm{X}=$ Input variable

$\mathrm{r}=$ The $1,2,3, \ldots \mathrm{s}$ output

$\mathrm{i}=$ The $1,2,3, \ldots \mathrm{m}$ input

$\mathrm{k}=$ Unit of economic activity

The results obtained are in the form of a profitable and efficient index achieved by each bank

\section{B. Analysis of Variance (ANOVA)}

This analysis is used to test the average difference when viewed from grouping based on a) banks that adopt and do not adopt fintech and b) banks that adopt and do not adopt fintech according to banking ownership. The testing is carried out using an error rate (alpha) of $5 \%$

\section{RESULTS AND DISCUSSION}

\section{A. Results}

The results of processing the banking profitability efficiency in 2018 are shown in table 1. The average values of efficiency for the banking group that adopt and do not adopt fintech are $90.14 \%$ and $91.49 \%$, respectively. Statistically, the test results concluded that Ho is accepted, which means there is no average difference in profitability, as shown by the p-value and F-statistics of $0.541>0.05$.

TABLE I. THE EFFICIENCY OF CONVENTIONAL BANKING BASED ON THE ADOPTION OF FINTECH AND THE BANK OWNERSHIP GROUP IN 2018

\begin{tabular}{|c|c|c|c|c|c|}
\hline \multicolumn{6}{|c|}{ Testing Efficiency Differences According to Fintech Adoption } \\
\hline Banking & n & Average & $\mathbf{S}_{\text {tatistic }}$ & P-value & Conclusion \\
\hline Fintech & 49 & 90.14 & \multirow[t]{2}{*}{0.377} & \multirow[t]{2}{*}{0.541} & \multirow{2}{*}{ Ho accepted } \\
\hline Non-Fintech & 47 & 91.49 & & & \\
\hline \multicolumn{6}{|c|}{ Testing of Differences According to Fintech Adoption and bank groups } \\
\hline Banking & $\mathbf{n}$ & Average & F-statistics & P-value & Conclusion \\
\hline Fintech State-owned Banks & 4 & 92.30 & \multirow[t]{7}{*}{2.727} & \multirow[t]{7}{*}{0.006} & \multirow[t]{7}{*}{ Ho rejected } \\
\hline Fintech Foreign Exchange Bank & 25 & 85.40 & & & \\
\hline Fintech Non-Foreign Exchange Bank & 2 & 100.00 & & & \\
\hline Fintech $B P D$ & 4 & 94.40 & & & \\
\hline Fintech Mixed Bank & 8 & 89.27 & & & \\
\hline Fintech Foreign Bank & 6 & 100.00 & & & \\
\hline Non-Fintech Foreign Exchange Bank & 11 & 87.75 & & & \\
\hline
\end{tabular}


Table 1. Cont.

\begin{tabular}{|l|l|l|l|l|l|}
\hline Non-Fintech Non-Foreign Exchange Bank & 14 & 86.91 & & & \\
\hline Non-Fintech $B P D$ & 19 & 96.12 & & & \\
\cline { 1 - 3 } Non-Fintech Mixed Bank & 1 & 81.40 & & & \\
\hline Non-Fintech Foreign Bank & 2 & 100.00 & & & \\
\hline Total & 96 & 90.47 & & & \multicolumn{3}{|c|}{ Source: processed data }
\end{tabular}

In conclusion that there is a significant difference between banks that use fintech based on ownership as shown by the pvalue and $F$ statistic of $0.006<0.05$. The calculation of banking efficiency levels in 2018 is explained as follows. The first rank is occupied by foreign banks that use/do not use fintech, and non-foreign exchange banks that use fintech with an optimal efficiency index of $100 \%$. The non-fintech BPD Bank occupies the second rank with an average efficiency level of $96.12 \%$. The third-place rank is occupied by fintech BPD with an average efficiency index of $94.40 \%$. The fourth rank is occupied by the fintech Persero Bank with an average efficiency index of $92.30 \%$. The banking group with the lowest rank is the non-fintech Mixed Bank, with an average value of $81.4 \%$.

Overall, the achievement of banking efficiency in Indonesia in 2018 is at a relatively high level, with an average value of $90.47 \%$. The efficiency levels based on the input and output variables used are shown in table 2 . The achievement of the three largest groups in terms of profitability and efficiency is explained as follows. The achievement of efficiency level in Foreign bank groups have achieved optimal results with an index of $100 \%$, it means that all inputs and outputs are in optimal condition. The State-owned bank group has a significant increase in the efficiency achievement of input and output levels. Out of the 10 variables used, only the Fixed Assets had an efficiency index of $62.27 \%$, which was below 90\%. Non-fintech BPD also has a high-efficiency achievement in its input and output structure. From the 10 variables, only 3 had an index below $90 \%$, namely the Fixed Asset $(87.33 \%)$, securities investment $(87.97 \%)$ and operation income (OPINC) at $79.48 \%$.

The achievement of the profitability and efficiency of other bank groups is generally at a reasonably good level except for the input salary structure of non-fintech mixed banks, which has a low-efficiency level, below 50\%. Table 2 provides a proper analysis of the data.

\section{B. Discussion}

The research findings showed that the adoption of fintech in the banking industry does not automatically lead to higher profitability and efficiency compared to other banks. The use of fintech in the banking industry depends on the type of banking ownership, and its characteristics are based on business activities. Foreign banking groups that achieve optimal efficiency levels have different characteristics. For instance, Citibank and Standard Chartered Bank are foreign banks that achieve optimal efficiency of $100 \%$ by using fintech, because their main activities are related to attracting customers. Different conditions occur in foreign banks such as Royal Bank of Scotland, The Hong Kong and Shanghai Banking Corp. The customers are segmented. Therefore, optimal banking efficiency is achieved without adopting fintech economics. A similar case occurred in non-fintech BPD banks, which ranked 3rd best in terms of achieving efficiency related to customers.

TABLE II. ThE EFFICIENCY OF INPUT AND OUTPUT STRUCTURES ACCORDING TO THE BANK GROUP IN 2018

\begin{tabular}{|c|c|c|c|c|c|c|c|c|c|c|}
\hline Banking & DEP & EQUITY & FIXAST & INTEXP & SALARY & OPEXP & LOANS & INVS & RINC & OPINC \\
\hline Fintech State-owned Banks & 92.30 & 92.30 & 62.27 & 92.30 & 92.30 & 92.30 & 100.00 & 100.00 & 100.00 & 90.57 \\
\hline Fintech Foreign Exchange Bank & 85.40 & 83.85 & 64.43 & 81.39 & 78.83 & 85.68 & 93.07 & 89.27 & 99.94 & 68.25 \\
\hline Fintech Non-Foreign Exchange Bank & 100.00 & 100.00 & 100.00 & 100.00 & 100.00 & 100.00 & 100.00 & 100.00 & 100.00 & 100.00 \\
\hline Fintech BPD & 94.40 & 94.87 & 65.27 & 94.87 & 88.30 & 94.87 & 88.10 & 84.37 & 100.00 & 56.30 \\
\hline Fintech Mixed Bank & 89.27 & 84.72 & 86.80 & 84.52 & 84.35 & 90.78 & 96.58 & 89.32 & 100.00 & 86.73 \\
\hline Fintech Foreign Bank & 100.00 & 100.00 & 100.00 & 100.00 & 100.00 & 100.00 & 100.00 & 100.00 & 100.00 & 100.00 \\
\hline Non-Fintech Foreign Exchange Bank & 87.75 & 87.75 & 79.84 & 84.77 & 83.75 & 87.75 & 93.31 & 94.78 & 100.00 & 68.15 \\
\hline Non-Fintech Non-Foreign Exchange Bank & 86.91 & 85.80 & 69.87 & 82.16 & 79.02 & 86.91 & 90.09 & 77.20 & 100.00 & 63.82 \\
\hline Non Fintech BPD & 96.12 & 96.65 & 87.73 & 96.65 & 94.67 & 96.65 & 97.68 & 87.97 & 100.00 & 79.48 \\
\hline Non-Fintech Mixed Bank & 81.40 & 81.40 & 81.40 & 81.40 & 48.20 & 81.40 & 100.00 & 100.00 & 100.00 & 53.50 \\
\hline Non-Fintech Foreign Bank & 100.00 & 100.00 & 100.00 & 100.00 & 100.00 & 100.00 & 100.00 & 100.00 & 100.00 & 100.00 \\
\hline Total & 90.47 & 89.65 & 77.29 & 88.12 & 85.86 & 90.80 & 94.74 & 89.36 & 99.98 & 74.94 \\
\hline
\end{tabular}

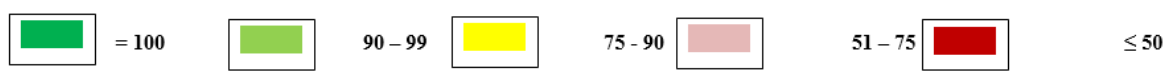

\section{CONCLUSION}

The following conclusions are drawn from the findings of this research. First, there are no significant differences in
Indonesian conventional banking that adopted/do not adopt the use of fintech. Second, there are significant differences in conventional banking when grouped based state-owned, private 
foreign and non-private foreign exchange, BPD, Mixed and foreign banks.

\section{REFERENCES}

[1] D. Arner, J. Barberis and R.P. Buckley, "FinTech, RegTech, and the Reconceptualization of Financial Regulation," S.A. Northwestern Journal of International Law \& Business, vol. 37, no. 3, pp. 371, 2017.

[2] J. Wonglimpiyarat, "FinTech banking industry: a systemic approach," Forep-valueht, vol. 19, no. 6, pp. 590-603, 2017.

[3] A.H. Abdul-Wahab and R. Haron, "Efficiency of Qatari banking industry: an empirical investigation," International Journal of Bank Marketing, vol. 35, no. 2, pp. 298-318, 2017.
[4] D.W. Arner, J. Barberis and R.P. Buckley, "The evolution of Fintech: A new post-crisis paradigm," Geo. J. Int'l L., vol. 47, pp. 1271, 2015.

[5] Financial Stability Board, FinTech Credit. Market Structure, Business Models and Financial Stability Implications [Online]. Retrieved from: https://www.bis.org, 2017a.

[6] Financial Stability Board, Financial Stability Implications. Supervisiory and Regulatory Issues that Merit Authorities Attention [Online]. Retrieved from: https://www.bis.org, 2017b.

[7] M.A. Nizar, "Teknologi Keuangan (Fintech): Konsep Dan Implementasinya Di Indonesia," Warta Fiskal, no. 5, pp. 5-15, 2017.

[8] P.W. Coopers, The Global State of Information Security® Survey 2018. Price Waterhouse Coopers, 2014. 